\title{
Readiness for Marriage among Students Base of Gender, Ethnic and Economic Strata
}

\author{
Lisa Putriani $^{1}$, Taufik Taufik ${ }^{2}$, Ifdil Ifdil ${ }^{3}$,Afdal Afdal ${ }^{4 *}$, \\ ${ }^{1234}$ Guidance \& Counseling Department, Faculty of Education, Universitas Negeri Padang, 25132, Padang, Indonesia
}

\begin{abstract}
This research purpose are to analyzed of the self readiness of students to get married base of gender, ethnic, and economic strata. The research method was ex post facto by used a factorial design $2 \times 2 \times 2$. The sample were 300 students used purposive random sampling technique. The instrument used Student Readiness Inventory (SRI). Data analyzed used of variance (ANOVA). The result showed: (1) the level of self readiness of graduate students to get married in general were in the high category, (2) the level of self readiness men and woman of graduate students to get married were in the high category, and there was difference of self readiness for graduate students to get married based on the gender, (3)the level of self readiness Patriarkhat and Matriarkhat culture of graduate students to get married were in the high category, and there was no difference based on the cultural background,(4)the level of self readiness graduate students to get married base of economic strata (have a regular job and do not have a permanent job) were in the high category, and there was no difference.
\end{abstract}

Keywords

Self readiness for married; Gender; Background culture; Economic conditions

Article Received: 20 September 2020, Revised: 30 November 2020, Accepted: 18 December 2020

\section{Introduction}

Guidance and counseling is a service for all individuals that refers to the overall human development, which includes dimensions of humanity in order to realize the whole human [1]. Humans are required to be able to develop and adapt to the environment, for that humans have been equipped with various potentials that exist in him. One of the goals of counseling is to help people make decisions [2] to move forward in the process of development. Various theories about individual development have been put forward by many experts, one of which is Havighurst who displays the term developmental task. Every individual who develops must complete the developmental tasks [3] in order to become a happy and successful individual.

The task of development is something that arises and is consistent at or around certain periods in an individual's life [4]. The concept of developmental tasks is based on the assumption that human development [5], including postgraduate students, is characterized by a series of tasks which individuals must study throughout their lives. The success of achieving certain developmental tasks is expected to give birth to happiness and success for individuals to complete subsequent tasks [6].
The period of early adult life takes place between the ages of 18-40 years [7]. Graduate students are generally in the early adulthood stages. Not only have duties and responsibilities towards academic, career and part of the social community, postgraduate students also have to fulfill their developmental duties as early adulthood.

According to Havighurst [1] developmental tasks in the early adult phase are: 1) choosing a life partner, 2) learning to live with a partner in marriage, 3) starting a family life, 4) caring for and educating children, 5 ) managing households, 6) starting work, 7) responsible as citizens, 8) finding matching social groups. Santrock [8] also argues that in essence an individual who has entered early adulthood has the characteristics of being economically independent, starting to accept responsibility for his behavior, being independent in making good decisions regarding decisions of close friends, a mate to be married, a career to be occupied as well as decisions regarding the future direction to be traversed. In this early adult phase, postgraduate students should mature in thinking to take responsibility and love for the couple who has become their choice, then they will get married and form a family. Lengan states that almost every young man (male and female) has two main objectives, first finding the right type of work; second, get 
married and build a household (family) [9]. Many factors influence a person to achieve both goals, one of which is a cultural factor. In choosing a life partner for example, considerations used by one culture are different from other cultures. Communities with Patriarchal culture are different from Matriarkhat cultural societies. Every society in the world has norms regarding marital matters. This means that marriage between men and women is not only a problem that is driven by biological factors, but is governed by various rules or norms that apply in social life [10] .

The results of the study related to the readiness of married students revealed that the problem with the highest percentage was the problem of psychological conflict between completing college and the desire to start working; but the problem of conflict with the desire to get married also began to be felt by students; a small number felt that parents were urged to get married soon, although they were still anxious because they did not yet have a prospective spouse and were still confused in choosing criteria that met expectations [11].

According to a longitudinal study conducted by that currently the number of early adults who do not have the confidence to build an intimate relationship increases. The results of [7] research on premarital counseling models oriented towards self-concept development, also suggested that students have not been able to act in accordance with positive considerations in preparing themselves for marriage. In addition, students have not been able to make a strict marriage commitment, which they can hold strongly as a principle, so that they are not independent and not confident. Their position is easily swayed and easily changes when under pressure or influence from their environment and they are not able to make plans for the future of their marriage properly. Kartono also revealed that many women who suffered greatly and were unhappy in marriage, were actually not caused by marital status, but were caused by being unprepared and their lack of ability to play several different roles or multiple roles. in marital status [12].

Nasikh 'Ulwan also stated that the obstacles for students to get married are economic difficulties and the cost of study, the assumption that marriage troublesome study, and shame for the family environment [13]. In addition to these aspects, [9] said that other factors that were taken into consideration in determining future marriage partners were similarities in terms of race, nation, religion and socioeconomic status. Specifically about socio-economic factors include various aspects, including those related to relationships and work. Wirdhana revealed that couples who have readiness to live a married life will be more receptive to and face all the consequences of problems that arise in marriage [14]. Some client problems found at university college counseling centers are anger/irritability, broken relationships, worries about dating, meaningful death of people, difficulty getting friends/loneliness, problems with husband or wife [15]. Counselors and student service personnel in counseling services at tertiary institutions emphasize general issues regarding the total development of the people they serve [15], including regarding student development tasks to be ready to choose and prevent occurrence problems and alleviation of problems related to marriage.

In carrying out their service assignments, counselors at tertiary institutions deal with developing individuals, including postgraduate students who are in their early adulthood. Therefore, in addition to the counselor having to understand in an integrated way the various aspects of individual development at the time the guidance and counseling service is provided, it must also be able to see the direction of the individual's development in the future (both near and farther future). In order for maximum counseling services, various aspects of development need to be a counselor's understanding of the face of the service goals, including regarding the readiness of marriage which is the task of developing postgraduate students. Yusuf \& Sugandhi revealed that selfreadiness to get married is very necessary with the aim that each partner can know, understand, and respond to marriage values that refer to the meaning and wisdom of marriage in family life [16]. The meaning and wisdom of marriage in family life for those who are in the phase of early adulthood, should be a provision for self-readiness to know, understand, and react positively to it 
which is used as a reference in building a harmonious and prosperous family life.

\section{Materials and Methods}

This research uses a quantitative approach to comparative descriptive type. The research method applied in this study is ex post facto with sampling data, the research will describe the readiness of postgraduate students to get married in terms of the sexes, namely the sexes of men and women, from Patriarchal and Matriarchal cultural backgrounds and economic conditions that are have a permanent job and do not have a permanent job.

This study aims to compare the readiness of postgraduate students to get married in terms of gender, cultural background and economic conditions. The study design uses a $2 \times 2 \times 2$ factorial design. The population in this study is unmarried graduate students. A total of 300 people were selected by cluster random sampling technique and combined with purposive sampling technique. The instrument used was a questionnaire that revealed the readiness to marry postgraduate students. Data obtained from respondents are processed and categorized into 5 categories, namely very high or very ready, high or ready, medium or sufficiently prepared, low or not ready and very low or very unprepared. Data were analyzed using variance analysis technique (ANAVA).

\section{Data Description}

The data obtained are arranged in a table that describes the respondent's data in a predetermined category, and then is described in the percentage value (\%) obtained. From Table 1 it can be understood that the degree of readiness of postgraduate students to get married in terms of gender, cultural background and overall economic conditions are in the high category $(\mathrm{T})$ with an average score (mean) of 196.8 and percentage of achievements against the ideal score amounted to $74.3 \%$. The highest mean (readiness) of marriage readiness is male graduate students with Matriarkhat cultural background and have permanent jobs with an average score of 208 and the percentage of achievement of the ideal score of $78.5 \%$. The lowest mean score (mean) of marriage readiness is female graduate students with a cultural background in Matriarchy and do not have a permanent job with an average score of 188.1 and the percentage of achievements to an ideal score of $71 \%$.

Table 1.Overview of self readiness of postgraduate students for marriage in terms of gender, cultural background and economic conditions

\begin{tabular}{|c|c|c|c|c|c|c|c|}
\hline Gender & Culture & Economic Conditions & $\begin{array}{c}\mathrm{N} \\
\text { (Sample) }\end{array}$ & $\begin{array}{l}\text { Mean } \\
\text { Score }\end{array}$ & SD & $\begin{array}{c}\% \\
\text { Mean }\end{array}$ & Category \\
\hline \multirow[t]{4}{*}{ Man } & \multirow[t]{2}{*}{ patriarchy } & Have a permanent job & 14 & 205,5 & 20 & 77,5 & $\mathrm{~T}$ \\
\hline & & $\begin{array}{l}\text { Do not have a } \\
\text { permanent job }\end{array}$ & 28 & 203,5 & 19,5 & 76,8 & $\mathrm{~T}$ \\
\hline & \multirow[t]{2}{*}{ matriarchy } & have a permanent job & 19 & 208 & 20,7 & 78,5 & T \\
\hline & & $\begin{array}{l}\text { Do not have a } \\
\text { permanent job }\end{array}$ & 41 & 196,5 & 21,9 & 74,2 & $\mathrm{~T}$ \\
\hline \multirow[t]{4}{*}{ Women } & \multirow[t]{2}{*}{ patriarchy } & Have a permanent job & 8 & 193 & 19,8 & 72,8 & T \\
\hline & & $\begin{array}{l}\text { Do not have a } \\
\text { permanent job }\end{array}$ & 36 & 189,3 & 24,2 & 71,4 & $\mathrm{~T}$ \\
\hline & \multirow[t]{2}{*}{ matriarchy } & Have a permanent job & 61 & 190,6 & 18,6 & 71,9 & T \\
\hline & & $\begin{array}{l}\text { Do not have a } \\
\text { permanent job }\end{array}$ & 93 & 188,1 & 25,8 & 71 & $\mathrm{~T}$ \\
\hline \multicolumn{3}{|l|}{ Total } & 300 & 196,8 & 21,3 & 74,3 & $\mathrm{~T}$ \\
\hline
\end{tabular}


Interaction Between Variables in Explaining the Readiness of Postgraduate Students to Get Married
The test was carried out using variance analysis technique (ANAVA). The results can be seen in Table

Table 2. Variant analysis (ANAVA) postgraduate student self readiness score data for married

\begin{tabular}{|l|c|c|c|c|c|c|}
\hline \multicolumn{1}{|c|}{ Variance } & $\mathrm{Jk}$ & $\mathrm{db}$ & $\mathrm{Rk}$ & $\mathrm{F}_{\text {hitung }}$ & $\mathrm{Sig}$ & Interpretation \\
\hline Male and female student scores & 10.579 .337 & 1 & 10.579 .337 & 21.021 & .000 & Significant \\
\hline $\begin{array}{l}\text { Student scores of patriarchal and } \\
\text { matriarchal culture }\end{array}$ & 1.182 .175 & 1 & 1.182 .175 & 2.184 & .141 & Not significant \\
\hline $\begin{array}{l}\text { Student scores have a permanent job } \\
\text { and do not have a permanent job }\end{array}$ & 1.075 .680 & 1 & 1.075 .680 & 1.986 & .160 & Not significant \\
\hline $\begin{array}{l}\text { The interaction of gender variables } \\
\text { and cultural background }\end{array}$ & 140.553 & 1 & 140.553 & .278 & .598 & Not significant \\
\hline $\begin{array}{l}\text { The interaction of gender variables } \\
\text { and economic conditions }\end{array}$ & 386.360 & 1 & 386.360 & .771 & .381 & Not significant \\
\hline $\begin{array}{l}\text { The interaction of cultural background } \\
\text { variables and economic conditions }\end{array}$ & 23.116 & 1 & 23.116 & .043 & 0.835 & Not significant \\
\hline $\begin{array}{l}\text { The interaction of gender variables, } \\
\text { cultural background and economic } \\
\text { conditions }\end{array}$ & 13.073 .802 & 7 & 1.867 .686 & 3.698 & .001 & Significant \\
\hline
\end{tabular}

The results of the analysis of variance (ANAVA) in Table 2 can be described as follows. From Table 2 it can be understood that there are significant differences in the readiness of postgraduate students to get married when viewed from their sexes, which means that gender determines the readiness of postgraduate students to get married.

Judging from the cultural background it can be understood that there is no significant difference in the readiness of postgraduate students to get married. It means that the cultural differences between Patriarch and Matriarchat do not determine the readiness of postgraduate students to get married. It was concluded that there were no significant differences in the readiness of postgraduate students who came from Patriarchal and Matriarchal cultural backgrounds to get married.

From the variable economic conditions it can be understood that there is no significant difference in the readiness of postgraduate students to get married. Means that the different economic conditions of graduate students who have permanent jobs and do not have permanent jobs do not determine the readiness of graduate students to get married.

\section{Discussion}

\section{Picture of Postgraduate Student Self Readiness for Married Judging from the Gender of Men and Women and the Differences}

The results of the data analysis show that the readiness to marry male and female graduate students is in the high category ( $\mathrm{T}$ ) or ready. Viewed in detail from the results of data analysis on married readiness of male and female graduate students it appears that the indicator of the highest average value compared to other indicators is the indicator of readiness for sexual relations, and the indicator with the lowest average value is the readiness to manage problems the economy.

It is understandable that in nature it is a developmental task for every individual who starts entering early adulthood to choose a life partner and learn to live with a partner in marriage because they already have a high level of 
readiness for sexual intercourse, and efforts are needed to prepare male and female graduate students women to get married through guidance and counseling services in higher education especially those related to readiness to manage economic problems in family life later, because the average value of this indicator is lower than other indicators in marriage readiness, so if this is left it is feared it will cause effects which is not good after graduate students get married. According to [17] financial problems also affect satisfaction in marriage, when the family economy is not yet stable, they must discuss the desire to buy things with a partner. Openness in terms of financial budget management and spending will make couples happier in marriage.

From the results of the study it was also found that the readiness of male and female graduate students to get married was different, the difference between the readiness of male and female graduate students was seen from the average value of all the existing indicators. This could be due to differences in the views of men and women regarding marriage [18]. The results of Light and Keller's research [9] that $60 \%$ of women stated that marriage was driven by factors of love and safety, but for men $70 \%$ stated that marriage is a matter of the desire to live together and reduce tension, while Love impulse factor ranks third.

In addition, one indicator that influences this difference is an indicator of economic readiness, for male graduate students economic factors are the most considered. This is because men will be responsible for providing dowry and sustenance for the welfare of their family life $[19,20]$, the primacy of men cannot be separated from their duties and obligations in providing protection and welfare for the family.

\section{Picture of Postgraduate Student Self Readiness for Married Judging from the Cultural Background of the Patriarch and Matriarchal and Their Differences}

The results of the data analysis showed that the readiness of postgraduate students to get married with cultural background Patriarch and
Matriarchal were in the high category $(\mathrm{T})$ or ready, the highest average score was on the indicator of readiness for sex, then the lowest average score was found on the indicator readiness to manage economic problems, and there is no significant difference between the marriage readiness of graduate students from Patriarchal culture and Matriarkhat culture.

In choosing a life partner, considerations used by one culture will be different from other cultures, every society in the world has norms regarding marital problems (Cashion, 1983: 311). However, the results of the study showed that there was no difference in the readiness to get married in each culture [18].

Patriarchal culture is a culture that places men higher than women. In a society that embraces Patriarchal culture women will find it difficult, but women who give birth to boys will get a high position. In terms of marriage, the status of women seems lower. The existence of inheritance and inheritance rights in the Batak tribe in boys tends to cause kamajuan for boys. The strength of the boy encourages the longing of a marriage to give birth to a son. His presence in a family gives hope about the continuation of their descent. In addition to the continuation of the descendants, the presence of boys in the family can increase the position and role of the father and mother in traditional ceremonies [21]. Therefore, the readiness to marry Patriarchal culture men is higher than the readiness to marry Patriarchal women.

In the patriarchal cultural marriage marriage is known as the payment of money from male relatives to female relatives with the aim of including women in her husband's clan. So that children born will be the next generation of fathers. Therefore, Patriarchal culture graduate students have lower average scores on indicators of readiness to manage economic problems than other indicators.

The Minangkabau community adopts a maternalistic system in which lineage follows the mother. In the Minangkabau community, it is women who hold power or are called Matriarchas, 
where adat is an instrument of protection for human values (humanism) which is ultimately internalized in social social life, so that the position of Minangkabau women has been glorified since the Minangkabau nature began to exist.

In the Matrilineal system women are positioned as a binder, guardian and custodian, as the traditional saying goes to the amban puruak or place of storage. That is why perhaps, in the determination of customary laws and regulations, women are not included. Women accept cleanly about rights and obligations in adat which have been decided before by the ninik mamak.

In the Minang community the position of men and women is in a balanced position. Men have the right to regulate everything in the marriages, both the usage arrangement, the distribution of inheritance, women as the owner can use all of the proceeds for the needs of children. In this case the role of men within and outside their people is something that must be carried out in a balanced and in line manner, in the Minangkabau community.

Outwardly and spiritually the owner of a house in Minangkabau is a woman. Men are passengers, and the shelter for them is surau (musholla). Since childhood (since elementary school age) boys are required to sleep separately with their parents and sisters. They were forced to sleep in groups in the mosque and no longer slept in their homes. Even though at present there is a mixing of life together between Minangkabau men and women, but the principle of this separate association still applies. This principle is internalized and accepted consciously by all Minangkabau residents, both those who occupy gadang houses and modern homes, both those who live in the Minangkabau realm and overseas [21].

Minangkabau youths do not have power in their clan, and are not given enough attention in their family environment. This feeling caused many Minangkabau youth to not feel at home in his family and / or in his village. In an effort to overcome such feelings or to show that he is a person who is needed, most young Minangkabau go abroad [21]. Their departure to overseas is generally temporary, not permanent. In the overseas area he tried his best to accumulate wealth by working hard. If a lot of wealth has been collected, they will return to their hometown with the results of the business they have collected. In this way the Minangkabau youth showed the family or community in their village that they could also act like their parents, maybe even surpass them.

In addition to economic factors, the educational factor helped encourage Minangkabau people to migrate, especially since the development of schools in the early 19th century. Unlike economic factors, migrating with the aim of seeking education was initially limited to a class of the population. At first it was limited to the children of local "dignitaries", for example respected civil servants and wealthy traders who wanted to raise their children's education to a higher level on the island of Java. But after 1969, when the opportunity to go to school was wide open, many Minangkabau youths each year went to continue their studies to Java [21]. In short, the desire to obtain a higher education helped encourage Minangkabau youth to migrate, including postgraduate students in their education.

\section{Picture of Readiness of Postgraduate Students to Get Married Viewed from the Economic Condition of Having a Permanent Job and Not Having a Permanent Job and the Difference}

The results of data analysis show that the readiness of married graduate students who have permanent jobs and do not have permanent jobs are both in the high category (T) or ready, as well as the readiness for marriage of graduate students who have permanent jobs or do not have permanent jobs the highest average score there is an indicator of readiness for sexual relations, then the lowest average score is an indicator of readiness to manage economic problems, with that value still being included in the high $(\mathrm{T})$ or ready category. Thus it can be understood that efforts need to be maintained and increase the readiness of married graduate students with guidance and counseling services, especially those related to readiness to manage economic problems. 
Economic factors in each individual affect the life in the family $[22,23]$. The higher cost of living and the higher cost of education, makes it common for Indonesian people both men and women to work to support the family's economic life. The family economy is one aspect in preparing for family life. Economic readiness is needed to meet family needs.

From the discussion above it can be concluded that the guidance and counseling services needed by postgraduate students, both postgraduate students who have permanent jobs and postgraduate students who do not have permanent jobs, especially services in the field of marriage preparation, because of the results of the analysis revealed that postgraduate students have jobs permanent or do not have a permanent job tends to have the lowest average score in terms of readiness to manage economic problems compared to other indicators.

\section{Conclusion}

Based on data or findings obtained in this study, where statistical analysis has been carried out and reviewed and elaborated in the discussion, it can be concluded that: first, overall, the degree of readiness of postgraduate students to get married is in the high category, the highest average of readiness for marriage is the male graduate student of Matriarkhat culture and has a permanent job and the lowest average readiness for marriage is the female graduate student of culture Matriarkhat and do not have a permanent job. Second, the level of readiness of postgraduate students to get married in terms of gender is in the high category and there are significant differences, where the mean score of male students is higher than female students, this means that male graduate students are more ready to get married compared to students female graduate.

Third, the level of readiness of postgraduate students to get married in terms of cultural background Patriarch and Matriarchal are in the high category. There is no significant difference in the readiness of postgraduate students based on Patriarch's and Matriarch's cultural background. Fourth, the level of readiness of postgraduate students to get married in terms of economic conditions is in the high category, there is no significant difference in the readiness of postgraduate students based on economic conditions who have permanent jobs and do not have permanent jobs. Fifth, there is no significant difference in the readiness of postgraduate students to get married when viewed from the gender and cultural background simultaneously.

Sixth, there is no significant difference in the readiness of postgraduate students to get married when viewed from gender and economic conditions simultaneously. Seventh, There is no significant difference in the readiness of postgraduate students to get married when viewed from the background of culture and economic conditions simultaneously. Eight, there is an interaction between gender, cultural background, and economic conditions in explaining the readiness of postgraduate students to get married.

\section{References}

[1] A. Pambudi, "Asimilasi Bagi Anak Pidana (Studi di Lembaga Pemasyarakatan Anak Kelas IIA Blitar)," Kumpulan Jurnal Mahasiswa Fakultas Hukum, vol. 1, 2013.

[2] K. Argyropoulou and A. Kaliris, "From career decision-making to career decisionmanagement: New trends and prospects for career counseling," Advances in Social Sciences Research Journal, vol. 5, 2018.

[3] N. Sanford, Self and society: Social change and individual development: Transaction Publishers, 2017.

[4] S. Gil and L. Le Bigot, "Colour and emotion: children also associate red with negative valence," Developmental science, vol. 19, pp. 1087-1094, 2016.

[5] B. M. Newman and P. R. Newman, Development through life: A psychosocial approach: Cengage Learning, 2017.

[6] R. Kaltiala-Heino, et al., "Gender dysphoria in adolescence: current perspectives," Adolescent health, medicine and therapeutics, vol. 9, p. 31, 2018. 
[7] R. A. Sturm and M. Larsson, "Genetics of human iris colour and patterns," Pigment cell \& melanoma research, vol. 22, pp. 544$562,2009$.

[8] T. Juliasari, "Kendala Penyelesaian Perkara Anak Melalui Diversi (Studi Kasus Putusan Nomor PUT. NO. 1/PIDSUS-Anak/2015 Pengadilan Negeri Mempawah)," Jurnal Fatwa Hukum, vol. 3, 2020.

[9] C. Lengen, "The effects of colours, shapes and boundaries of landscapes on perception, emotion and mentalising processes promoting health and well-being," Health \& place, vol. 35, pp. 166-177, 2015.

[10] A. M. Sewenet, et al., "Interreligious Marriage: Social and Religious Perspectives," Imperial Journal of Interdisciplinary Research, vol. 3, pp. 233250, 2017.

[11] R. Quaglia, et al., "A new theory on children's drawings: Analyzing the role of emotion and movement in graphical development," Infant Behavior and Development, vol. 39, pp. 81-91, 2015.

[12] M. L. Woody, et al., "Children's sustained attention to emotional facial expressions and their autonomic nervous system reactivity during parent-child interactions," Biological psychology, vol. 142, pp. 37-44, 2019.

[13] L. Goldner, et al., "A glance at children's family drawings: Associations with children's and parents' hope and attributional style," The Arts in Psychotherapy, vol. 43, pp. 7-15, 2015.

[14] C. Beauregard, et al., "Connecting identities through drawing: Relationships between identities in images drawn by immigrant students," The Arts in Psychotherapy, vol. 56, pp. 83-92, 2017.

[15] M. Casarrubea, et al., "The impact of chronic daily nicotine exposure and its overnight withdrawal on the structure of anxiety-related behaviors in rats: Role of the lateral habenula," Progress in Neuro-
Psychopharmacology and Biological Psychiatry, vol. 105, 2021.

[16] S. Yusuf and N. M. Sugandhi, "Perkembangan peserta didik," Jakarta: PT Raja Grafindo Persada, 2011.

[17] E. B. Hurlock, Developmental psychology: Tata McGraw-Hill Education, 2001.

[18] S. F. Duncan, et al., "Individual Personality and Emotional Readiness Characteristics Associated with Marriage Preparation Outcomes of Perceived Helpfulness and Change," Journal of Couple \& Relationship Therapy, vol. 17, pp. 209-226, 2018.

[19] B. K. K. B. Nasional, "Pendidikan kesehatan reproduksi bagi calon pengantin," Jakarta: $B K K B N, 2009$.

[20] S.-S. Park, et al., "Treadmill exercise ameliorates nicotine withdrawal-induced symptoms," Journal of Exercise Rehabilitation, vol. 15, p. 383, 2019.

[21] H. Nirwana, "Hubungan Tingkat Aspirasi dan Persepsi tentang Belajar dengan Hasil Belajar Matematika Siswa Sekolah Menengah Umum yang Berlatar Belakang Budaya Minangkabau dan Batak," Disertasi Tidak Diterbitkan. Malang: Program Studi Psikologi Pendidikan Pascasarjana UM, 2003.

[22] J. Hackl and D. Krause, "Effects of modular product structures on life phases and economic factors," in DS 84: Proceedings of the DESIGN 2016 14th International Design Conference, 2016, pp. 1285-1294.

[23] T. Li, et al., "Culture, economic development, social-network type, and mortality: Evidence from Chinese older adults," Social Science \& Medicine, vol. 204, pp. 23-30, 2018. 